\title{
(JIPD)
}

Jurnal Inovasi Pendidikan Dasar

Vol. 4, No. 2, Bulan Juli Tahun 2020, Hal. 91-98

E-ISSN: 2598-408X, P-ISSN: 2541-0202

http://unikastpaulus.ac.id/jurnal/index.php/jipd

https://doi.org/10.36928/jipd.v4i2.356

\section{PENGARUH PEMBELAJARAN TUTOR SEBAYA TERHADAP PRESTASI BELAJAR SISWA KELAS VII PADA POKOK BAHASAN SEGI EMPAT SEMESTER II SMPK IMMACULATA RUTENG TAHUN AJARAN 2018/2019"}

\author{
Sebastianus Fedi ${ }^{1}$, Maria Helena Ose Blikololong ${ }^{2}$, Eufrasia Jeramat ${ }^{3}$ \\ ${ }^{1,3}$ Prodi Pendidikan Matematika, Unika Santu Paulus, Ruteng 86511, Indonesia. \\ ${ }^{3}$ SMPK Immaculata Ruteng \\ sebastianusfedi@gmail.com
}

Diterima: 11 Januari 2020, Direvisi: 15 Mei 2020, Diterbitkan: 15 Juli 2020

\begin{abstract}
This study aims to determine the effect of peer teaching model on the learning achievement of grade VII students, on the rectangular subject at SMPK Immaculata Ruteng, Flores, NTT.The research method was an experimental method, with post-test only control group design.Sampling of the experimental and control classes was carried out by a random class procedure, which preceded by an equivalence test through Anava.The research sample for the experimental class was 31 students, treated with peer tutoring learning models. And the research sample for the control class was 30 students, using conventional learning models. The instrument of this research was a test instrument in the form of description. The data analysis showed that the experimental group got an average value of 79,77while the control group got an average value of 65,83 . Calculation on data for the hypothesis test, we obtained $t_{\text {observation }}=4,1736$ and $t_{(5 \%, 59)}=1.6711$. Because $t_{\text {observation }}>$ $t_{(5 \%, 59)}$ then $H_{0}: \mu_{1}=\mu_{2}$ is rejected and $\mathrm{H}_{1}: \mu_{1}>\mu_{2}$ is accepted.In this case, $\mu_{1}=$ the average value of the learning achievement of the experimental class, while $\mu_{2}=$ the average value of the learning achievement of the control class.Means, student learning achievement taught by peer tutor learning models is higher than student learning achievement taught with conventional learning models.So, in an effort to build student mathematics learning achievement, peer tutoring learning models are more effective than conventional learning models.
\end{abstract}

\section{Keywords: Peer Teaching, Learning Achievement}

\begin{abstract}
Abstrak: Penelitian ini bertujuan untuk mengetahui pengaruh PembelajaranTutor Sebaya terhadap prestasibelajar siswa kelas VII, pada materi segi empat di SMPKImmaculata Ruteng. Metode penelitian yang digunakan adalah metode eksperimen dengan post-test only control group design.Pengambilan sampel kelas eksperimen dan kontrol, dilakukan dengan prosedur random kelas, yang didahului uji kesetaraan melalui Anava. Sampel penelitian untuk kelas eksperimenberjumlah 31 siswa, mendapat perlakuan model pembelajaran tutor sebaya. Sampel penelitian untuk kelas kontrol berjumlah30 siswa, menggunakan modelpembelajaran konvensional. Instrumen yang digunakan dalam penelitianadalahinstrument tes berbentuk uraian. Hasil analisis data menunjukkan bahwa kelompok eksperimen mendapatkan nilai rata-rata 79,77 sedangkan kelompok kontrol mendapat nilai rata-rata 65,83 . Perhitungan untuk uji hipotesis diperoleh hasilt $t_{\text {hitung }}=4,1736$ dan $t_{5 \%, 59}=$ 1,6711. Karenat $t_{\text {hitung }}>t_{5 \%, 59}$ maka $H_{0}: \mu_{1}=\mu_{2}$ ditolakdan $H_{0}: \mu_{1}>\mu_{2}$ diterima. Dalam hal ini, $\mu_{1}=$ nilai rata-rata prestasi belajar kelas eksperimen dan $\mu_{2}=$ nilai rata-rata prestasi belajar kelas kontrol. Berarti, prestasi belajar siswa yang diajarkan dengan modelpembelajaranTutor Sebaya lebih tinggi dari pada prestasi belajar siswa yangdiajarkan denganmodel pembelajaran konvensional. Kesimpulannya adalah dalam upaya membangun prestasi belajar matematika siswa, model pembelajarantutor sebaya lebih efektif
\end{abstract} dibandingkandengan model pembelajaran konvensional.

Kata Kunci: Pembelajaran Tutor Sebaya, Prestasi Belajar 


\section{PENDAHULUAN}

Pendidikan adalah proses hakiki bagi manusia,yang berlangsung secara berkesinambungan sepanjang usia, dengan tujuan mendapatkan kecakapan hidup dan memperbaiki kualitas hidup. Berarti, pendidikan merupakan suatu kebutuhan hidup untuk meningkatkan Sumber Daya Manusia (SDM). Dalam UndangUndang Nomor 20 tahun 2003 tentang Sistem Pendidikan Nasional, pemerintah Indonesia mendefinisikan bahwa:"Pendidikan adalah usaha sadar dan terencana untuk mewujudkan suasana belajardan proses pembelajaran agar peserta didik secara aktif mengembangkan potensi dirinya, untuk memiliki kekuatan spiritual, keagamaan, pengendalian diri, kepribadian, kecerdasan, ahlak mulia serta keterampilan yang diperlukan dirinya, masyarakat bangsa dan negara".

Menurut Joni (2007: 4)perkembangan pendidikan dalam masyarakat akan membawa pengaruh terhadap perkembangan nilai dan konsep di dunia pendidikan. Tujuan utama pendidikan adalah untuk memberikan dasardasar pengetahuan, keterampilan, keahlian bertahan hidup dan pengalaman belajar yang membangun integritas sosial serta mewujudkan karakternasional.

Pemerintah Indonesia, secara terukur dan sistematis, telah berusaha mewujudkan cita-cita pendidikan nasional dengan memprogramkan dan menjalankan kurikulum pendidikan nasional. Muatan kurikulum dirancang untuk mendukung tujuan pendidikan sebagaimana dalam UU No 20 tahun 2003, tentang Sisdiknas.

Dalam kurikulum pendidikan kita, matematika ditetapkan sebagai salah satu ilmu utama pada kurikulum PAUD, SD, SMP, SMA hingga Perguruan Tinggi. Hal ini merupakan kebijakan yang layak, kerena matematika mempunyai peranan yang sangat penting dalam perkembangan Ilmu Pengetahuan,Teknologi dan Seni (IPTEKS). Perkembangan IPTEKS sangat tergantung pada kemampuan manusia, sebagai sumber daya utama yang menghasilkan ide dan karya cipta. Sementara, matematika merupakan ilmu utama yang membentuk keterampilan dan kecakapan manusia, karena dengan matematika, manusia bisa membangun penalaran logis dan kemampuan berpikir yang kompleks. Matematika juga merupakan disiplin ilmu yang memiliki hubungan sangat kuat dengan disiplin ilmu lain.

Menurut Crockkoft (Abdurrahman, 2012), alasan matematika diajarkan kepada siswa, karena matematika selalu digunakan dalam segala segi kehidupan, sebagai sarana komunikasi yang kuat, singkat, dan jelas, digunakan untuk menyajikan informasi dalam berbagai cara, dan meningkatkan kemampuan berpikir logis, karakter ketelitian, kemampuan spasial/logika 3 dimensi (kesadaran keruangan), dan kemampuan pemecahan masalah.

Dengan peranan yang begitu krusial dan luas cakupannya, matematika bukanlah mata pelajaran mudah. Fakta bahwa secara umum manusia masih menganggap matematika sebagai mata pelajaran yang paling sulit.Matematika dianggap ilmu tersulitkarena matematika mengandalkan logika dan penalaran, sifatnya abstrak, serta dijejali berbagai simbol dan rumus.

Selain itu, untuk jenjang pendidikan lanjutan, faktor kemampuan dan pengalaman pribadi siswa dalam belajar matematika, juga menjadi alasan matematika dianggap sulit.Misalnya, sering gagal atau tidak mampu membuat penjelasan solusi masalah matematika di kelas, mendapat nilai paling rendah dalam tugas/ujian matematika dibandingkan mata pelajaran lainnya, dan kesan buruk terkait faktor guru matematika di kelas. Kesan buruk terhadap guru matematika terjadi karena tidak optimal, metode dan pelaksanaan pembelajaran yang tidak menarik, atau ada sikap tidak profesional dalam menyelenggarakan pembelajaran matematika.

Tiga faktor utama yaitu sifat-sifat matematika, kemampuandan pengalaman pribadi siswa, faktor guru,dan ditambah faktor keempat yaitu sarana belajar yang tidak memadai, menimbulkan masalah rendahnya mutupendidikanmatematika. Indikatornya adalah rendahnya rata-rata prestasi belajar matematika siswa.

Hal ini dapat diketahui dari hasil penelitian yang dilakukan oleh Trends in International Mathematics and Science Study (TIMSS) sebagaimana dikutip oleh Hadi dan Novaliyosi (2019), seperti pada tabel 1.

Tabel 1. Peringkat TIMSS Tahun 2015untuk Indonesia

\begin{tabular}{|c|c|c|c|c|}
\hline \multicolumn{5}{|c|}{ HASIL TIMSS } \\
\hline Tahun & Peringkat & Peserta & $\begin{array}{c}\text { Rata-rata Skor } \\
\text { Indonesia }\end{array}$ & $\begin{array}{c}\text { Rata-rata Skor } \\
\text { International }\end{array}$ \\
\hline
\end{tabular}




\begin{tabular}{|l|l|l|l|l|}
\hline 2003 & 35 & 46 negara & 411 & 467 \\
\hline 2007 & 36 & 49 negara & 397 & 500 \\
\hline 2011 & 38 & 42 negara & 386 & 500 \\
\hline 2015 & 44 & 49 negara & 397 & 500 \\
\hline
\end{tabular}

Dari faktor guru dan siswa, masalahterjadi pada desain dan pelaksanaan pembelajaran. Sering terjadi, pembelajaran masihdidominasi oleh guru (teacher centered).Siswa menjadi pendengar dan peniru. Siswa diarahkan untuk mengikuti gaya berpikir dan prosedur penyelesaian yang telah mampu dilakukan oleh guru. Hasnawati (2006: 54) menyatakan bahwaguru lebih banyakmenempatkan siswa sebagai objekdan bukansebagai subjek didik.Pendidikan kitakurang memberikan kesempatan kepada siswadalam berbagai mata pelajaran, untuk mengembangkan kemampuanberpikir holistik, kreatif, objektif, dan logis.Belum memanfaatkanquantum learning sebagai salahsatu paradigma menarik dalam pembelajaran, serta kurang memperhatikan ketuntasan secara individual.

Untuk mengubah paradigma lamaseperti di atas, dikreaiskan modelpembelajaran termutakhir,yang diklaim bahwa secara teoretis lebih efektif membangun prestasi belajar siswa. Salah satunya adalah model Pembelajaran Tutor Sebaya (Peer Teaching).

Secara teoretis, Pembelajaran Tutor Sebaya akan mengaktifkan semua siswa dalam kelas. Karena, keunggulan Pembelajaran Tutor Sebaya adalah: (1) mengaktifkan seluruh warga kelas. Dalam hal ini, siswa yang telah memahami diberi kesempatan membagikan ilmu kepada temannya yang belum memahami, sehingga terjadi diskusi dan seluruh siswa menjadi aktif; (2)dengan tutor sebaya, suasana pembelajaran matematika menjadi rileks.Secara psikokognitif, keakraban dan hubungan rileks pada teman sebaya merupakan potensi terjadinya komunikasi ilmiah yang santai dan mudah terkoneksi.Sedangkan komunikasi siswa dengan guru bisa lebih kaku karena siswa merasa segan atau siswa memandang guru sebagai high level personal.Bahasa teman sebaya lebih mudah dipahami. Pada teman sebaya tidak ada rasa enggan, tidak merasa rendah diri, tidak merasa malu sehingga tidak ada halangan untuk bertanya ataupun minta bantuan. Bahasa dan gestur teman sebaya lebih akrab dan memudahkan pembelajaran.(3)membangun karakter percaya diri pada siswa. Ini terjadi karena pembelajaran tutor sebaya mengarahkan siswa untuk menyampaikan pendapat ilmiah. Makin sering pembelajaran tutor sebaya siswa makin terlatih untuk mengutarakan idenya, siswa makin meningkatkan kepercayaan dirinya. Dampak lebih jauh adalah siswa makin terbiasa dan makin mampu melahirkan ide dan menyampaikan gagasan ilmiah. Ini sangat membantu dalam pembelajaran mata pelajaran apa pun.(4) Membangun karakter komunikasi dan kerjasama. Kesempatan menjadi tutor akan membangun kemampuan komunikasi dan membangun karakter kerjasama, ini dua hal yang berpengaruh terhadap prestasi belajar. (5) Memudahkan siswa memahami konsep ilmu. Hal ini berkaitan dengan sifat dasar manusia bahwa dalam keadaan rileks, manusia lebih mudah beraktifitas dibandingkan dengan dalam keadaan kaku. Tutor sebaya membuat siswa belajar dalam keadaan rileks.

Ke lima hal di atas juga menjadi dasar pertimbangan bahwa apapunpendekatan pembelajaran yang diterapkan harusberorientasi pada siswa atau terpusat padasiswa(student centered),dan bukan terpusatpada guru(teacher centered).

Pertimbangan lain terhadap pembelajaran tutor sebaya adalah siswa merupakan unsur pokok dalam pembelajaran,maka siswalah yang harus menerima dan mencapai berbagai informasi pengajaran yang pada akhirnya dapat mengubah tingkah lakunya sesuai dengan yang diharapkan. Untuk itu, maka siswa harus dijadikan sebagai sumber pertimbangan didalam pemilihan sumber pengajaran (Sudirman, dkk 1987).

Arikunto (1986) menyatakan bahwa tutor sebaya adalah seseorang atau beberapa orang siswa yang ditunjuk oleh guru sebagai pembantu guru dalam melakukan bimbingan terhadap kawan sekelas.

Menurut Gintings (2014), langkahlangkah pembelajaran Tutor Sebaya adalah: (a) membagi siswa menjadi beberapa kelompok dengan 5-6 orang per kelompok, di mana tiap kelompok memiliki minimal seorang siswa berkemampuan tinggi.Pada tiap kelompok, guru matematika menugaskan seorang siswa yang berkemampuan terbaik sebagai tutor;(b) guru menyampaikan sekilas informasi tentang materi pembelajaran; (c) guru memberikanLKS dan 
menjelaskan prosedur pengerjaan tugas pada LKS; (d) guru memberi kesempatan bertanya kepada siswa tentang LKS; (e) Masing-masing tutor menjalankan fungsi tutorial dan mengkoordinirproses diskusi agar berlangsung kreatifdan dinamis; (f) guru mengawasi kegiatan belajar siswa selama diskusi berlangsung danmembantu siswa jika ada yang mengalami kesulitan dalam menyelesaikansoal-soal yang terdapat di LKS; (g) secara acak, guru memanggil siswa dari setiap kelompok untuk membahas masalah di depan kelas (membahas solusi soal pada LKS);h) guru memberikan penghargaan kepada kelompok (dan individu yang tampil) yang menjawabdengan benar. (i) guru membimbing siswa membuat rangkuman tentang materi yang dibahas; (j) guru memberikan test akhir pembelajaran kepadaseluruh siswa.

Sebagai perbandingan adalah pembelajaran konvensional. Pembelajaran konvensional adalah pembelajaran yang didominasi ceramah oleh guru, sedangkan siswa hadir sebagai pendengar, mencatat, dan mengerjakan soal latihan sesuai contoh yang diberikan oleh guru. Akibatnya, siswa menjadi lebih pasif, siswa hanya mengikuti pikiran guru, tidak optimal mengembangkan penalaran siswa, dan mematikan kreatifitas siswa.Sehingga tujuannya adalah siswa mengetahui sesuatu, bukan mampu melakukan sesuatu.

Ini telah banyak merugikan pendidikan di In2donesia, di mana tampak bahwa secara teoretis hebat, tetapi lemah dalam penerapannya dan lemah dalam hal membentuk keterampilan siswa. Sehingga muncul ungkapan'sarjana di atas kertas'.

Freire (1999) menyatakan bahwa pembelajaran konvensional adalah bentuk pembelajaran bergayabank. Artinya, pembelajaran dipandang sebagai suatu aktifitas pemberian informasiyang harus 'ditelan' siswa, yang wajib diingat dan dihafal.MenurutSukandi (2003) pembelajaran konvensional ditandai dengan guru lebih banyak mengajarkan konsepkonsep, bukan melatih kompetensi siswa.

Materi pelajaran disampaikan secara lisan, atau disertai tulisan di papan tulis. Siswa diminta memperhatikan dan dan atau mencatatnya. Kemudian siswa mengerjakan soal latihan, dan dinilai oleh guru. Kadang-kadang guru memberikan PR atau tugas tambahan. Di Indonesia,pembelajaran konvensional dikenal sebagai pembelajaran tradisional yang umum dipakai sejak dahulu, sebelum reformasi politik terjadi tahun 1998.

Syahrul (2013) menyatakan bahwa

langkah-langkah pembelajaran

konvensionalsebagai berikut: (1) menyampaikan tujuan pembelajaran; (2)menyajikan informasi, di mana secara bertahap melalui metode ceramah, guru menyajikan materi pelajaran; (3). Mengecek pemahaman dan memberikan umpan balik. Guru mengecek keberhasilan siswa dan memberikan umpan balik. (4)memberikan kesempatan latihan lanjutan, berupa tugas tambahanuntuk dikerjakandi rumah.

Tampak bahwa secara teoretis, pembelajaran tutor sebaya lebih bagus daripada konvensional. Dengan tutor sebaya, diharapkansiswa dapatmakin mandiridalam belajar, mengembangkan pengetahuan,dan mampu mengomunikasikan gagasanlewat diskusi kelompok dan pembahasan di depan kelas. Guruberperansebagaifasilitatordan narasumber saja.

Sekolah Menengah Pertama Katolik (SMPK) Immaculata Ruteng dalamproses pembelajaranyang menggunakan kurikulum 2013. Pokok bahasan segi empat merupakan salah satumateri pokok semester ganjil yang dibelajarkan pada siswa kelas VII.Berdasarkan hasil wawancara pada pertengahan Oktober 2018, ditemukan kenyataan bahwabanyak siswamengalami kesulitan dalam belajar matematika. Ditemui juga, siswa berpendapat bahwa matematika merupakanmatapelajaran yang sulit dan membosankan. Menurutguru mata pelajaran matematika,dalam pembelajaransiswakurang aktif bertanya atau mengerjakan tugas yang berikan guru secara mandiri dan siswa sering tidak menganggap penting pelajaran sehingga dapat memicu prestasi belajar siswa yang tidak maksimal. Hal tersebut dapat dilihat dari nilai ujian semester ganjil tahun ajaran 2018/2019.

Tabel 2.Deskripsi Nilai UjianSemester Ganjil 2018/2019 Kelas VIII SMPK

\begin{tabular}{|c|c|c|c|}
\hline \multirow{2}{*}{ No } & \multirow{2}{*}{ Kelas } & \multicolumn{2}{|c|}{ Nilai } \\
\cline { 3 - 4 } & & Terendah & Tertinggi \\
\hline 1 & $\mathrm{~A}$ & 48 & 98,5 \\
\hline 2 & $\mathrm{~B}$ & 34,5 & 100 \\
\hline 3 & $\mathrm{C}$ & 43 & 100 \\
\hline 4 & $\mathrm{D}$ & 50 & 100 \\
\hline 5 & $\mathrm{E}$ & 47 & 84 \\
\hline 6 & $\mathrm{~F}$ & 47 & 100 \\
\hline
\end{tabular}




\begin{tabular}{|l|l|l|l|}
\hline 7 & $\mathrm{G}$ & 34 & 100 \\
\hline
\end{tabular}

(Sumber: SMPK Immaculata Ruteng)

Kriteria ketuntasan minimum (KKM) matematika di sekolah ini adalah 75. Nilai ratarata kolektif kelas VII adalah 51,61. Berarti secara umum prestasi belajar matematika siswa kelas VII masih di bawah KKM.

Rentang nilai siswa yang tertinggi dengan siswa yang terendah adalah 100-34=66. Data ini menunjukkan kesenggangan yang sangat mencolok antara siswa berkemampuan tinggi dan berkemampuan rendah. Dengan nilai rataan yang masih di bawah KKM, maka perlu ada perbaikan pembelajaran.

Beberapa masalah ditemukan di lapangan sebagai berikut: (1) Matematika dianggap mata pelajaran paling sulit; (2) Terjadi pembelajaran yang tidak optimal; (3) Prestasi belajar dan hasil belajar siswa masih rendah; (4) Terjadinya perbedaan nilai yang sangat mencolok antara siswa terpintar dengan siswa yang kurang pandai; (5) Belum diterapkanya model pembelajaran yang mengaktifkan seluruh siswa.

Dengan paparan seperti di atas, dipertimbangkan untuk menerapkan pembelajaran tutor sebaya dalam pembelajaran matematika di sekolah ini. Sebelum itu, perlu dibuat penelitian terkait pembelajaran tutor sebaya. Maka kami telah menjalankan penelitian eksperimen di mana kelas eksperimen menggunakan pembelajaran tutor sebaya, sedangkan kelas kontrol menggunakan pembelajaran konvensional.

Tujuan penelitian ini adalah menjawab masalah 'apakah pembelajaran tutor sebaya lebih efektif daripada pembelajaran konvensional?'. Dihipotesiskan bahwa hasil belajar pada kelas berpembelajaran tutor sebaya lebih unggul daripada hasil berlajar pada kelas berpembelajaran konvensional. Hipotesis ini dibangun dengan mengacu pada teori yang dipaparkan sebelumnya, di mana jelas secara teoretis bahwa pembelajaran tutor sebaya lebih unggul daripada pembelajaran konvensional.

Solusi atas masalah ini akan dijawabmelalui penelitian eksperimen, di mana prestasi belajar antara kedua kelompok eksperimen akan dibandingkan melalui uji statistika. Jawaban masalah ini adalah berupa rekomendasi ilmiah terkait model pembelajaran tutor sebaya.

\section{METODE PENELITIAN}

Penelitian ini merupakan penelitian kuantitatif dengan metode eksperimen semu (quasi-experiment). Berdasarkan pendapat Sugiyono(2015) tentang eksperimen semu, makapenelitian ini mengkajisuatu tindakan (intervensi) yang bersifat empiris yang digunakan untuk memperkirakan dampak sebabakibat (causal effect) dari tindakan tersebutpada populasi target tanpa pengacakan pada populasi.

Desain eksperimenyang digunakan adalah Posttest-Only Control Group Designyang diadopsi dari Arikunto (2010). Sasaran utama penelitian iniadalah melihat pengaruh positif modelpembelajaran tutor sebaya terhadap prestasi belajar siswa. Sebagai kelas pembanding, digunakan metode konvensional pada suatu kelas yang disebut kelas kontrol. Kelas berpembelajarantutor sebaya sebagai kelas eksperimen, dan kelas yang berpembelajaran konvensional disebut kelas kontrol. Prestasi belajar awal atau keadaan awal kelas eksperimen dan kontrol adalah setara, sesuai hasil uji kesetaraan.

Tabel 3. Desain Penelitian

\begin{tabular}{|c|c|c|}
\hline Kelas & Perlakuan & Posttest \\
\hline R1 & $\mathrm{X}$ & $\mathrm{O} 1$ \\
\hline R2 & - & $\mathrm{O} 2$ \\
\hline
\end{tabular}

Keterangan:

$\mathrm{R} 1=$ kelas eksperimen

$\mathrm{R} 2$ = kelas control

$\mathrm{X}=$ perlakuan, pembelajaran tutor sebaya

$\mathrm{O} 1=$ hasil observasi kemampuan akhir

kelas eksperimen

$\mathrm{O} 2=$ hasil observasi kemampuan akhir kelas control

Hipotesis yang diuji adalah:

$H_{0}=$ Prestasi belajar siswa yang berpembelajaran Tutor Sebaya tidak lebih baik dibandingkan dengan prestasi belajar siswa yang berpembelajaran konvensional.

$H_{1}=$ Prestasi belajar siswa yang berpembelajaran TutorSebaya lebih baik dibandingkan dengan prestasi belajar siswa yang berpembelajaran konvensional.

Hipotesis secara statistika:

$$
\begin{aligned}
& H_{0}: \mu_{1} \leq \mu_{2} \\
& H_{0}: \mu_{1}>\mu_{2}
\end{aligned}
$$


Keterangan:

$$
\begin{aligned}
\mu_{1}= & \text { Rata-rata prestasi belajar } \\
& \text { matematika siswa yang } \\
& \text { berpembelajarantutor sebaya. } \\
\mu_{2}= & \text { Rata-rata prestasi belajar siswa } \\
& \text { yang berpembelajaran } \\
& \text { konvensional. }
\end{aligned}
$$

Hipotesis diuji dengan taraf signifikansi $95 \% \quad($ dengan $\alpha=$ $5 \%$ ), derajat kebebasann $n_{1}+$ $n_{2}-2$, dengan ketentuan: (i) $H_{0}: \mu_{1} \leq \mu_{2} \quad$ ditolak jika

$t_{\text {hitung }} \leq t_{\text {tabel }}$

$H_{0}: \mu_{1} \leq \mu_{2} \quad$ diterima jika

$t_{\text {hitung }}>t_{\text {tabel }}$

\section{HASIL DAN PEMBAHASAN}

Dalam penelitian ini sampelyang digunakan berjumlah 61 siswa dengan rincian 31 siswa pada kelas eksperimen dan 30 siswa pada kelas kontrol.Statistik deskriptif seperti tabel4.

Tabel 4. Tabel Deskripsi Data Penelitian

\begin{tabular}{|l|c|c|}
\hline \multirow{2}{*}{\multicolumn{1}{|c|}{ Statistika }} & \multicolumn{2}{c|}{ Kelas } \\
\cline { 2 - 3 } & Eksperimen & Kontrol \\
\hline Jumlah Siswa & 31 & 30 \\
\hline Nilai Maksimum & 99 & 87 \\
\hline Nilai Minimum & 45 & 30 \\
\hline Rata-rata & 79.77 & 65.83 \\
\hline Median & 81 & 70 \\
\hline Modus & 85 & 70 \\
\hline Simpangan Baku & 10.82 & 14.83 \\
\hline Varians & 117.11 & 221.38 \\
\hline
\end{tabular}

Hasil uji normalitas menunjukkan bahwa masing-masing kelompok data berdistribusi normal. Hasil uji homogenitasmenujukkan bahwa variansi kedua kelompok data homogen. Maka, maka pengujian hipotesis menggunakan uji-t. berikut:

Hasil perhitungan uji-t seperti pada table

Tabel 5. Hasil Perhitungan Statistik Uji Hipotesis

\begin{tabular}{|l|c|c|c|c|}
\hline \multicolumn{1}{|c|}{ Kelas } & $\begin{array}{c}\text { Nilai } \\
\text { rata-rata }\end{array}$ & Varians & $t_{\text {hitung }}$ & $t_{\text {tabel }}$ \\
\hline Eksperimen & 79.77 & 117.11 & \multirow{2}{*}{4,174} & \multirow{2}{*}{1,671} \\
\hline Kontrol & 65.83 & 221.38 & & \\
\hline
\end{tabular}

Karenat $t_{\text {hitung }}>t_{\text {tabel }}$ maka $\quad H_{0}: \mu_{1} \leq$ $\mu_{2}$ ditolak, dan $H_{0}: \mu_{1}>\mu_{2}$ diterima. Artinya, prestasi belajar siswa yang berpembelajaran Tutor Sebaya lebih baik dibandingkan dengan prestasi belajar siswa yang berpembelajaran konvensional. Sehingga hipotesis yang menyatakan keunggulan metode tutor sebaya diterima.

Dengan keadaan awal kedua kelompok sampel yang setara, maka hasil penelitian ini menunjukkan bahwa pembelajaran matematika dengan modelpembelajaran tutor sebaya dapatmemberikan pengaruh positif dan signifikan terhadap prestasibelajar siswa.
Hasil penelitian ini membuktikan kebenaran teori belajar Vygotsky (1978), yang menyatakan bahwa suatu pengetahuan tidak diperoleh secara sendiri oleh siswa, melainkan mendapat bantuan darilingkungannya.

Dalam hal ini perlakuan yangdiberikan pada kelas eksperimen yaitu pembelajaran dengan model tutor sebayabenar-benar membantu siswa, yaitusiswa memperoleh pengetahuan baru karena berinteraksi dengan teman sebaya didalam kelompok. Secara ilmiah, terbukti bahwa teman sebaya dapat diandalkan sebagai sumberbelajar, menjadi sumber dayalingkunganyang sangat positif untuk pengembangan kemampuan matematika siswa.

Sebagaimana teori yang umum diketahui tentang metode tutor sebaya dan metode konvensional, maka dapat diklaim faktor-faktor yangmenjadi keunggulan modelpembelajaran tutor sebaya dibandingkan dengan model pembelajaran konvensional adalah sebagi berikut:

a) Pada model pembelajaran tutor sebaya, pembelajaran dalam bentuk kelompok dengan bantuan LKS membuat semua siswa menjadi aktif. Siswa belajar dengan cara 'melakukan bersama-sama' melalui diskusi dan aksi Bersama temannya. Sedangkan dalam pembelajaran konvensional, dominasi 
guru mengurangi aktifitas belajar siswa. Ceramah dan contoh yang diberikan guru memaksa siswa menjadi pendengar dan peniru. Sehingga pembelajaran konvensional membuat siswa pasif dan kakuseperti 'menyakiskan tayangan'.

b) Matematika adalah ilmu yang abstrak dan kaku. Pembelajaran tutor sebaya, menciptakan suasana yang rileks, karenaterjadi komunikasi ilmiah yang santai dan tidak terbatas. Komunikasimenjadi mudah terkoneksisebab sumber belajar adalah teman sebaya yang membuat perilaku belajar tidak canggung. Sedangkan dalam pembelajaran konvensional, komunikasi siswa dengan guru menjadi sangat terbatas, bisa lebih kaku karena siswa merasa segan atau siswa memandang guru sebagai figur yang lebih tinggi. Pembelajaran konvensional membuat matematika yang abstrak dan kaku makin kaku dan menakutkan.

c) Karena tiap siswa aktif dan tidak dibatasi untuk berdiksui, maka pembelajaran tutor sebaya membangun karakter percaya diri pada siswa. Ini terjadi karena pembelajaran tutor sebaya mengarahkan siswa untuk menyampaikan pendapat ilmiah. Makin sering terlibat dalam pembelajaran tutor sebaya, siswa makin terlatih untuk mengutarakan idenya, siswa makin meningkatkan kepercayaan dirinya, dan siswa makin terlatih menggunakan penalaran matematikanya. Dampak lebih jauh adalah siswa makin terbiasa dan makin mampu melahirkan ide dan menyampaikan gagasan ilmiah. Ini sangat membantu dalam pembelajaran mata pelajaran apa pun. Sedangkan dalam pembelajaran konvensional, mendengar ceramah dan meniru contoh hanya mendidik siswa menjadi penurut pada ide orang lain, mendidik siswa untuk menghafal dan mengingat.

d) Membangun karakter komunikasi dan kerjasama. Menjadi tutor atau mengutarakan pendapat akan membangun kemampuan komunikasi dan membangun karakter kerjasama.Ini dua hal yang berpengaruh terhadap prestasi belajar. Sedangkan pada pembelajaran konvensional, siswa cenderung pasif dan hampir tidak ada latihan kerja sama dalam bentuk bertukar pikiran. Kalau pun terjadi, itu tidak dilakukan secara sistematis dan terorganisir, sehingga hanya siswa tertentu 'yang mampu' yang dapat melakukannya.

e) Memudahkan siswa memahami konsep ilmu. Hal ini berkaitan dengan sifat dasar manusia bahwa dalam keadaan rileks, manusia lebih mudah beraktifitas dibandingkan dengan dalam keadaan kaku. Tutor sebaya membuat siswa belajar dalam keadaan rileks, tidak canggung. Sedangkan pembelajaran konvensional membuat siswa berada dalam suasana 'terpaksa' diminta memerhatikan, entah suka atau tidak suka dengan gaya penampilan dan penyampaian materi oleh guru. Ini membuat siswa sulit mengembangkan pikiran, sehingga sulit memahami konsep ilmunya.

\section{KESIMPULAN}

Berdasarkan hasil pengolahan dan analisis data penelitian ini, dengan menerapkan model pembelajaran tutor sebayayang telah dilakukan di SMPK Immaculata Ruteng tahun ajaran2018/2019, dapat disimpulkanbahwa terkait prestasi belajar matematika siswa, model pembelajaran tutor sebaya lebih berpengaruh positif dibandingkan dengan model pembelajaran konvensional.

\section{DAFTAR RUJUKAN}

Abdurrahan. 2012. Pendidikan Bagi Anak Berkesulitan Belajar. Rineka Cipta. Jakarta.

Arikunto, Suharsimi, 1986. Pengelolaan Kelas dan Siswa. Jakarta: Rajawali.

Arikunto, Suharsimi. 2010. Prosedur Penelitian. Jakarta: Rineka Cipta

Freire, P. 1999. Politik Pendidikan, Kebudayaan, Kekuasaan dan Pembebasan. Yogyakarta:Pustaka Pelajar.

Gintings. A. 2014. Esensi Praktis Belajar dan Pembelajaran disiapkan untuk Pendidikan Profesi dan Sertifikasi GuruDosen. Bandung: Humaniora.

Hadi, Syamsul dan Novaliyosi. 2019.Timss Indonesia (Trends In International Mathematics And Science Study).Tasikmalaya: Prosiding Seminar Nasional. Program Studi Magister 
Pendidikan Matematika Universitas

Siliwangi.

Hasnawati. 2006. Pendekatan Contextual

Teaching Learning Hubungannya dengan

Evaluasi Pembelajaran. Jurnal Ekonomi

\& Pendidikan, Volume 3 Nomor 1, April 2006.

Joni, R. 2007. Wawasan Pendidikan dan

Pembaharuan Pendidikan Guru. Pustaka Belajar. Malang

Sudirman. N. dkk. 1987. Ilmu Pendidikan. Remaja Karya. Bandung.

Sugiyono. 2015. Metode Penelitian

Sukandi, Ujang. 2003. Belajar Aktif dan Terpadu. Surabaya: Duta Graha Pustaka.

Syahrul, Muh. 2013. Model dan Sintaks

Pembelajaran Konvensional http://www.wawasanpendidikan.com/201 3/08/model-dan-sintakspembelajarankonvensional.html. (Diakses pada 8Pebruari 2019)

Vygotsky. L. S. 1978. Mind in Society.

Cambrydge: Harvard Univesity. Press. 